читацьких рецептивних домінант, горизонту очікувань та корелювання культурно-світоглядних площин автора і читача.

\title{
Література:
}

1. Гілберт Е. Природа всіх речей. Львів : Видавництво Старого Лева, 2016. $704 \mathrm{c}$.

2. Лукач Д. К онтологии общественного бытия. М., 1991. 417 с.

3. Трубников В.М. Время человеческого бытия. М., 1987. $256 \mathrm{c.}$

4. Dharmawan, B. Ambrose pike's moral behavior in the signature of all things novel by Elizabeth Gilbert. Universitas Jenderal Soedirman, 2016. URL: http://repository.unsoed.ac.id/2268/ (дата звернення: 23.10.2020).

5. Raechel, J., English R. Transition of self: Repositioning the celebrity brand through social media - The case of Elizabeth Gilbert. Journal of Business Research, 2016. Vol. 69 (1). P.65-72. DOI: https://doi.org/10.1016/ j.jbusres.2015.07.021.

DOI https://doi.org/10.30525/978-9934-588-90-7-23

\section{ФЕНОМЕН «БАЙСТРЮЦТВО»: ВІД ДАВНИНИ ДО СЬОГОДЕННЯ ( ЗА РОМАНОМ М. ХІМИЧ «БАЙСТРЮЧКА»)}

\author{
Ласкава Ю. В. \\ кандидат філологічних наук, \\ стариий викладач \\ Запорізький національний університет \\ м. Запоріжжя, Україна
}

Уже багато століть у нашому світі ведуться суперечки над проблемою батьків і дітей. Кожне покоління намагається якнайглибше пірнути у вир цих проблем задля того, аби віднайти ту золоту середину, яка б стала прийнятною для обох сторін. Та чи вона взагалі існує? Адже всі проблеми в родині виникають через таємниці, брехню, неповагу тощо. На теренах українського літературознавства, проблему родини у своїх роботах висвітлили такі українські науковці як $Н$. Бернадська, Г. Грабович, Г. Клочек, В. Шевчук та ін.

Яскравим прикладом занепаду родини є діти-безбатченки, або, як кажуть в народі - байстрюки. Слов'янська народна мораль, як i християнство, конкретизуючи поняття гріха, відносять до нього 
народження дитини поза шлюбом. Шлюб вважається найважливішим соціальним інститутом, у якому зосереджені всі моральні, матеріальні та духовні риси кожного іiі члена. Але з часом більшість соціальних канонів знищується, або частково розмивається ї зміст. Так, наприклад, поняття «позашлюбних дітей». Крім юридичнонейтрального терміну «позашлюбна дитина», в українській мові $є$ слово «байстрюк». Воно має образливий, лайливий зміст, що відображає ставлення українців до таких дітлахів, каже мовознавець Олександр Пономарів [3]. Прийшло воно до нас з польської мови, А і в польську, i німецьку, і французьку слово прийшло з латини. У цій мові «bastardus» утворене від «bastum», що означає «сідло» [3]. Хоча традиційне українське суспільство минулих століть не сприймало безбатченків, в літературних творах цей образ був просякнутий особливою авторською симпатією і ніжністю, каже письменник Володимир Яворівський: «Можна починати від Катерини Шевченка, продовжувати Стефаником, в якого ця тема розвивалася, i аж до нашого часу. Я б назвав Григора Тютюнника «Вогник далеко в степу» [2].

Проте у сучасному суспільстві до дітей, народжених поза шлюбом, ставляться адекватно, образливі слова на зразок «байстря» можна почути рідше, ніж раніше. Психолог Катерина Скороходько впевнена, що крім тиску зовнішнього світу на таку дитину, існують й інші проблеми [4]. Зокрема, формування образу майбутньої сім'ї починається з самого дитинства. Тож у малят, яким не вистачає спілкування 3 татами, часто можуть бути проблеми у спілкуванні з протилежною статтю, але сучасні мами-одиначки впевнені, що виховувати дитину самій - це нормально. Адже краще формувати маленьку особистість у любові та ніжності, ніж би вона чула постійні сварки, або мала батька-алкоголіка, ще й до того ледацюгу [4]. Ось тому завдяки родинним таємницям, переосмисленню теми «байстрюцтва» на сучасний лад і виник роман Марії Хімич «Байстрючка». Спочатку твір був написаний у жанрі повісті, але у 2015 році нею зацікавилося харківське видавництво та запропонувало розширити текст. I ось, у 2016 році, на полицях книжкових магазинів ми можемо бачити вже роман «Байстрючка», який був удостоєний міжнародної недержавної українсько-німецької літературної премії імені Олеся Гончара. Ця книжка, за словами автора, - спроба навчити батьків поважати своїх дітей, їхнє право знати сімейні «страшні» таємниці. Діти мають знати про помилки своїх батьків, хоча б для того, щоб їх не повторити [2].

Сюжет твору побудований на долях двох родин - Коляди та Письки. Головні герої - Ксенька і Марк - безбатченки, байстрюки. Кожен з них 
має свою історію. Ксенька Коляда на 12 році життя під час перепалки 3 сестрою Варварою випадково дізнається, що вони нерідні і їі справжнє прізвище Писька: «Коли Варварка розповіла про мого справжнього біологічного батька, здалося, що в мене вставили останній шматочок пазла, якого не вистачало для повноцінного малюнку моєї свідомості й без якого вона була неповноцінною та розхлябаною» [5, с. 20]. Але, нажаль, батько помер коли Ксеньці було трохи більше 2 років. Дівчинка завжди відчувала неприязнь з боку вітчима, коли той приходив у гості до старшої сестри, ніколи не дивився на неї очима, сповненими любові, хоча мати 3 вітчимом вже довгий час й жили окремо. У той доленосний день, Ксенька вперше промовила вголос те, що давно їй боліло: «А я - безбатченко, котра ніколи не знала, що це таке - мати тата» [5, с. 20]. Після відвертої розмови з матір'ю, дівчинка дізналася, що в неї багато рідних по татовій лінії, які й гадки не мають про існування позашлюбної доньки Назара Письки. Але найбільше іiі зацікавив зведений брат, і у голові Ксеньки закрався хробачок з'їздити до сусіднього міста та познайомитись 3 ним. Так вона і вирішила зробити, коли настане слушна година. Наступного тижня мати зі старшої сестрою вирішили поїхати до бабусі, залишивши Ксеньку вдома. Для неї це був знак, що час збиратися на електричку, назустріч новому життю.

Під час своєї маленької мандрівки, в електричці, дівчинка знайомиться 3 хлопцем Марком. Серед сірої та буденної маси його вирізняв кислотнобілий ірокез, який з першої хвилини привернув увагу маленької Ксеньки. Цей момент зародження світлих почуттів можна вважати зав'язкою роману . Але доля вирішила зіграти з ними злий жарт: Марк виявився тим самим братом, до якого так поспішала Ксеня. Марія Хімич майстерно відтворює почуття та емоції дітей-байстрюків, брата і сестри, які мали необережність закохатися один в одного. Та чи існують перепони, що здатні завадити закоханим бути разом? Тут і починається розкриття таємниць двох родин, адже для того, щоб розплутати клубочок, варто лише потягнути за кінець. Після приїзду зведеної сестри і перед Марком почали відкриватися родинні таємниці: Зіна, його мати, врешті-решт розповіла синові, що Назар нерідний його батько. Світ закрутився перед очима хлопця і його пазли теж склалися докупи. Усе своє життя хлопець ніяк не міг змиритися з рудим від природи кольором волосся, у цьому він був зовсім не схожий на батьків, хоча мати запевняла всіх в тому, що Марк $\epsilon$ копією їі двоюрідного дідуся . Хлопцю дошкуляло те, що в школі його прозивали «Рудько», тому він і перефарбувався в кислотно-білий і зробив ірокез. Та в їх містечку проживав ветеринар Ярослав, який мав точно такісінький колір волосся, і Марко не раз підмічав це, вважавши його своїм 
далеким родичем. А як потім виявилося, не таким вже й далеким: Ярослав рідний батько Марка. 3 одного боку це була приголомшлива новина для обох чоловіків і жоден 3 них не знав як тепер їм поводитися. Та час розставив все по місцях: проблеми в родині Ксені згуртували сина і батька, а після смерті Зіни у хлопця тільки й він і залишився. Дружина Ярослава не була проти Марка, бо той не заглядав до їх кишені та всіляко допомагав у господарстві Ярославу.

Роман завершується перемогою правди над брехнею. Ксеня вийшла заміж за Марка після закінчення школи та вступила до Київського університету на заочне відділення за спеціальністю «Дизайн», бо мала хист до малювання та іноді виставляла свої картини на місцеві виставки. Марко, створивши власне агропідприємство, став успішним бізнесменом, налагодив стосунки з батьком. На щастя, доля цих двох дітейбайстрюків склалася в тиху та спокійну річку, бо кожен має право на своє місце під сонцем. Задум роману простежується у завершальних словах Ксеньки, стосовно своєї картини-пророцтва, де зображені Марк i Ксеня: «У цій картині - моя віра в те, що байстрюки мають право знати правду й чесно говорити про неї. Вони - це не сором для родини. Байстрюки - це лише діти, які довірливо дивляться на цей світ і чекають від нього маленького дива...» [5, с. 220].

Отже, роман Марії Хімич зачіпає дуже інтимну тему, тему-табу. Про таке не прийнято говорити в голос, тим більш в пострадянському середовищі. Та письменниця змогла доторкнутися до душі кожного читача, розбурхати іï та змусити говорити правду, поважати своїх дітей та бути уважними до їх проблем.

\section{Література:}

1. Бабійчук Т. Проблеми сім'ї на сторінках художніх творів української літератури. Украӥнська література в загальноосвітній школі, 2015. Вип. № 4. С. 23-26.

2. Інтерв'ю Олександра Трохимчука з Марією Хімич. Точка доступу: http://vgolos.zt.ua/5884.html (дата звернення: 17.10.2020).

3. Пономарів О. Стилістка сучасної української мови. Київ : Либідь, 1992. $248 \mathrm{c}$.

4. Скороходько К. Вплив суб'єктивного стану самотності на розвиток децентрації у ранньому юнацькому віці : Зб. наук. праць. Випуск 8. Київ, 2012. Режим доступу: www.psyh.kiev.ua (дата звернення: 30.09.2020).

5. Хімич М. Байстрючка : роман. Харків : Книжковий клуб «Клуб Сімейного Дозвілля», 2016. 224 с. 